\title{
Nature of the Retrograde Signal from Injured Nerves that Induces Interleukin-6 mRNA in Neurons
}

\author{
Patricia G. Murphy, ${ }^{1}$ Lindsay S. Borthwick, ${ }^{1}$ Robert S. Johnston, ${ }^{1}$ George Kuchel, ${ }^{2}$ and Peter M. Richardson ${ }^{1}$ \\ Divisions of ${ }^{1}$ Neurosurgery and ${ }^{2}$ Geriatrics, Montreal General Hospital and McGill University, Montreal, Canada H3G 1 A4
}

In previous studies, interleukin-6 was shown to be synthesized in approximately one-third of lumbar dorsal root ganglion neurons during the first week after nerve transection. In present studies, interleukin-6 mRNA was found to be induced also in axotomized facial motor neurons and sympathetic neurons. The nature of the signal that induces interleukin- 6 mRNA in neurons after nerve injury was analyzed. Blocking of retrograde axonal transport by injection of colchicine into an otherwise normal nerve did not induce interleukin-6 mRNA in primary sensory neurons, but injection of colchicine into the nerve stump prevented induction of interleukin- 6 mRNA by nerve transection. Therefore, it was concluded that interleukin- 6 is induced by an injury factor arising from the nerve stump rather than by interruption of normal retrograde trophic support from target tissues or distal nerve segments. Next, injection into the nerve of a mast cell degranulating agent was shown to stimulate interleukin-6 mRNA in sensory neurons and systemic administration of mast cell stabilizing agents to mitigate the induction of interleukin- 6 mRNA in sensory neurons after nerve injury. These data implicate mast cells as one possible source of the factors that lead to induction of interleukin- 6 mRNA after nerve injury.

In search of a possible function of inducible interelukin-6, neuronal death after nerve transection was assessed in mice with null deletion of the interleukin- 6 gene. Retrograde death of neurons in the fifth lumbar dorsal root ganglion was $45 \%$ greater in knockout than in wild-type mice. Thus, endogenous interleukin- 6 contributes to the survival of axotomized neurons.

Key words: axotomy; dorsal root ganglion; interleukin-6; mast cells; peripheral nerve injury; neuronal death
Interleukin-6 (IL-6) is virtually absent in the peripheral nervous system (PNS) of normal mature animals but after sciatic nerve transection is induced for $\sim 1 \mathrm{~d}$ in the nerve (Zhong and Heumann, 1995; Bourde et al., 1999) and $\sim 1$ week in a subpopulation of medium and large lumbar dorsal root ganglion (DRG) neurons (Murphy et al., 1995). IL-6 mRNA persists in axotomized neurons much more briefly than growth-associated protein-43 (GAP43) mRNA and other induced mRNAs. This relative brevity suggests that the inductive signal from the injured nerve might be unusual.

After nerve transection, nerve cell bodies undergo many retrograde reactions (Lieberman, 1971), including alteration of neuropeptides and ion channels (Hökfelt et al., 1994; Verge et al., 1995; Zhang et al., 1997; Cummins and Waxman, 1998), and synthesis of molecules that promote regeneration (McQuarrie and Grafstein, 1973; Richardson and Issa, 1984; Skene, 1989). Most of these responses can be attributed to interruption of normal retrograde trophic support from target tissues and/or distal nerve segments (Lieberman, 1974; Gordon et al., 1991). Pharmacological inhibition of retrograde axonal transport with microtubule-binding proteins, such as colchicine or vinblastine, mimics many of the neuronal and perineuronal responses of DRG neurons to nerve transection (Landmesser and Pilar, 1974; Aldskogius and Svensson, 1988; Woolf et al., 1990; Leah et al., 1991). Some of the changes in DRG neurons can be attributed to loss of

\footnotetext{
Received Aug. 10, 1998; revised March 1, 1999; accepted March 9, 1999.

This work was supported by grants to P.M.R. from the Medical Research Council of Canada and the International Institute for Research in Paraplegia. P.G.M was supported by a fellowship from the Rick Hansen Man in Motion Foundation, and L.B. was supported by a studentship from the Medical Research Council of Canada. Correspondence should be addressed to Peter Richardson, Division of Neurosurgery, Montreal General Hospital, 1650 Cedar Avenue, Montreal, Canada H3G 1A4. Copyright (C) 1999 Society for Neuroscience $0270-6474 / 99 / 193791-10 \$ 05.00 / 0$
}

retrograde influence of specific molecules, such as NGF (Fitzgerald et al., 1985; Verge et al., 1995) and glial-derived neurotrophic factor (Bennett et al., 1998). Other changes are caused by interruption of retrograde transport of unknown molecules (Verge et al., 1990).

In response to sufficient stimuli, mast cells quickly release many products from preformed granules and initiate several inflammatory processes, in addition to acute hypersensitivity (Wershil et al., 1988; Galli, 1993; Echtenacher et al., 1996; Malaviya et al., 1996; Kubes and Granger, 1996). After peripheral nerve crush, mast cells in the immediate vicinity are rapidly degranulated (Olsson, 1967). Degranulation of mast cells contributes to the pain elicited by NGF (Lewin and Mendell, 1994; Woolf et al., 1996) and to other pathological processes in peripheral nerves (Brosman et al., 1985; Zochodne et al., 1994; Dines and Powell, 1997).

An extreme neuronal response to axonal interruption is death, at least sometimes because of apoptosis (Berkelaar et al., 1994). Neuronal death is thought to be caused by loss of retrograde trophic support from target tissues and/or glial cells (Lieberman, 1974; Pettmann and Henderson, 1998) and can be reduced by exogenous trophic agents (Li et al., 1994).

Data presented here indicate that the induction of IL-6 mRNA in DRG neurons is initiated by an injury factor from the nerve stump to which mast cells may contribute and that endogenous inducible IL-6 attenuates the death of axotomized neurons.

\section{MATERIALS AND METHODS}

Surgery for nerve manipulations in rats. Adult female Sprague Dawley rats weighing $\sim 200 \mathrm{gm}$ were anesthetized with Pentothal $(50 \mathrm{mg} / \mathrm{kg}$, i.p.) and submitted to a variety of microsurgical procedures. (1) The right sciatic nerve was exposed in midthigh and either transected (three rats) or crushed (three rats) with jeweler's forceps for $10 \mathrm{sec}$, while the left sciatic 
nerve was uninjured. Rats were killed 4-7 d later. (2) In three rats, the L5 dorsal root was sectioned with microscissors $2 \mathrm{~mm}$ from its DRG. Rats were killed 4-7 d later. (3) In three rats, the right facial nerve was exposed near the stylomastoid foramen and transected with removal of a $2 \mathrm{~mm}$ segment to impede regeneration. The completeness of the transection was confirmed by observations of whisker paralysis and failure of eye closing. Rats were killed 2-7 d later. (4) In four rats, the external and internal postganglionic nerves were transected several millimeters from the superior cervical ganglion, or the preganglionic cervical sympathetic trunk was severed proximal to the ganglion. Rats were killed $4 \mathrm{~d}$ later.

Nerve injections. Two to $5 \mu \mathrm{l}$ of $5 \mathrm{~mm}$ colchicine, $0.25-1.0 \mu \mathrm{g}$ of the mast cell degranulating compound 48/80 (Sigma, St. Louis, MO), normal rat serum, or saline were injected slowly into the right sciatic nerve in midthigh through a glass micropipette with a tip diameter of $\sim 50 \mu \mathrm{m}$ attached to a manual pressure injection system filled with mineral oil (Beitz and King, 1979). Colchicine was injected in uninjured nerves (three rats), in the stump or distal segment of transected nerves (three rats), or in contralateral nerves (three rats). Colchicine, injected intraneurally at this dose, has been shown to block axonal transport for at least $5 \mathrm{~d}$ (Richardson and Verge, 1986). A total of 14 rats were injected with $48 / 80$. In three rats, recombinant tumor necrosis factor- $\alpha$ (TNF- $\alpha$ ) was injected into the sciatic nerve and, in three rats, IL- $1 \beta$.

Intraperitoneal injections. Two mast cell stabilizing agents were injected individually and intraperitoneally in combination with sciatic nerve transection at midthigh in an attempt to influence the induction of IL-6 mRNA in DRG neurons. Cromolyn sodium $(1 \mathrm{ml} / \mathrm{kg}$ of a $1 \%$ solution) (Sigma) or ketotifen $(1 \mathrm{ml} / \mathrm{kg}$ of a $1 \%$ solution) were injected twice a day for $5 \mathrm{~d}$ before surgery and for a further $5 \mathrm{~d}$ until the rats were killed. Three rats were injected in each of the two groups, and three control rats underwent nerve transection alone.

In situ hybridization. In most experiments, L4 and L5 DRG were removed, frozen immediately in $N$-methyl butane at $-55^{\circ} \mathrm{C}$, embedded in Tissue-Tek (Miles, Elkhart, IN), and stored at $-70^{\circ} \mathrm{C}$. DRG to be compared were embedded in the same mold. Where appropriate, superior cervical ganglia or the brainstem were removed, in the latter case, after perfusion of the rats per aorta with PBS. Antisense oligonucleotides for IL-6 (Murphy et al., 1995) or GAP-43 (Verge et al., 1990), 50 nucleotides in length, were labeled with ${ }^{33} \mathrm{P}$ by the terminal transferase reaction. Frozen sections cut on a cryostat set at 5-10 $\mu \mathrm{m}$ were thaw mounted on Probe-On slides (Fisher Scientific, Houston, TX) and hybridized $16-18 \mathrm{hr}$ at $42^{\circ} \mathrm{C}$ with a solution containing $500,000 \mathrm{cpm}$ oligonucleotide, $50 \%$ formamide, $4 \times$ SSC, $100 \mathrm{mg} / \mathrm{ml}$ dextran sulfate, $1 \%$ sarcosyl, $500 \mu \mathrm{g} / \mathrm{ml}$ salmon sperm DNA, and $200 \mathrm{~mm}$ DTT. After hybridization, the sections were washed four times in $1 \times \mathrm{SSC}$ at $55^{\circ} \mathrm{C}$ for $15 \mathrm{~min}$, fixed briefly in 65 and $95 \%$ ethanol, dried, dipped in radiosensitive emulsion (Kodak NTB2; Eastman Kodak, Rochester, NY), exposed in the dark at $4^{\circ} \mathrm{C}$ for $4-6$ weeks, developed, fixed, and stained with $0.002 \%$ toluidine blue.

Neuronal labeling for IL-6 mRNA was quantified with a computerized image analysis system (Richardson et al., 1989) for groups of two to four sections on the same slide. Only cells with a visible nucleolus were quantified. The percentage of cross-sectional area covered by silver grains was measured, and a correction factor was applied to yield a parameter linearly related to grain number. Labeling index refers to the ratio of grain density over neurons to grain density over non-neuronal regions of the DRG.

Neuronal cell counts after nerve transection in mice. Nine male C57BL6/ 129 mice aged 9 weeks and nine mice of the same strain with null mutation of the IL-6 gene (Kopf et al., 1994) were anesthetized by intramuscular injection of $0.75 \mathrm{mg} / \mathrm{gm}$ ketamine and $0.01 \mathrm{mg} / \mathrm{gm}$ xylazine. Through a midline dorsal incision, the right sciatic nerve was transected at its origin from the L4 and L5 spinal nerves, while the left sciatic nerve was uninjured.

Fourteen days after nerve transection, ipsilateral and contralateral L5 DRG were removed from deeply anesthetized mice. The DRG were fixed overnight in $4 \%$ formaldehyde, washed three times with PBS, protected overnight in $18 \%$ sucrose, and frozen in cryomolds at $-55^{\circ} \mathrm{C}$ in $N$-methyl butane. Serial frozen sections were cut on a cryostat set at 5 $\mu \mathrm{m}$, thaw mounted onto gelatin-coated slides, and stained with $0.002 \%$ toluidine blue. Neurons with clearly visible nucleoli were counted under oil immersion light microscopy in every fifth section by an observer blinded to the mouse genotype. No correction was made for split nucleoli. Percentage survival was calculated from the ratio of ipsilateral to contralateral counts.

\section{RESULTS \\ Motor and sympathetic neurons synthesize IL-6 mRNA after nerve injury}

Experiments were performed to determine whether nerve injury induces IL-6 mRNA in PNS neurons that were not DRG neurons.

In sections of the brainstem from rats killed 2-4 d after facial nerve transection, IL-6 mRNA was detected by in situ hybridization in neurons of the ipsilateral, but not contralateral, facial motor nucleus (Fig. 1). In semiquantitative analysis of two nuclei, 64 (89 of 141) and 65\% (90 of 138) of neurons were deemed to be labeled, including few or no small motoneurons. With this technique of in situ hybridization, IL-6 mRNA was not detected in non-neuronal cells. The data support a prediction (Klein et al., 1997) that at least some of the IL-6 mRNA detected in the facial motor nucleus after nerve transection (Kiefer et al., 1993) is in neurons.

After transection of the postganglionic sympathetic nerves, but not after transection of the preganglionic trunk, IL-6 mRNA was found in many sympathetic neurons in the superior cervical ganglion (Fig. 1). Again, no hybridization signal was detected in non-neuronal cells of the superior cervical ganglion. In contrast to a previous report (Marz et al., 1996), we did not detect IL-6 mRNA in sympathetic neurons of uninjured mature rats or contralateral superior cervical ganglia.

The results of these experiments indicate that, after nerve injury, IL-6 mRNA is induced in many neurons in the corresponding motor nucleus or sympathetic ganglion.

\section{IL-6 mRNA is induced in some DRG neurons by nerve crush or dorsal spinal nerve root transection}

After sciatic nerve crush, IL-6 mRNA was detected in L5 DRG neurons, albeit in fewer neurons than after nerve transection (data not shown). Transection of the L5 dorsal spinal root elicited clear IL-6 mRNA labeling in a few (2-5\%) L5 DRG neurons. After section of a dorsal spinal nerve root, most neurons in the corresponding DRG are not visibly perturbed (Carmel and Stein, 1969; but Hare and Hinsey, 1940) GAP-43 (Chong et al., 1994) and c-jun (Jenkins et al., 1993) are found in a few neurons, as is IL-6 mRNA. IL-6 mRNA is induced in DRG neurons after nerve crush or dorsal spinal nerve root transection but in fewer neurons than after nerve transection.

\section{A signal from injured nerves stimulates IL-6 synthesis in DRG neurons}

Colchicine was injected intraneurally to investigate whether interruption of retrograde axonal transport mimics or blocks the induction of nerve transection. Injections were either into a previously uninjured nerve or immediately proximal to the site of nerve transection. Three days after the rats were killed, GAP-43 and IL-6 mRNAs were analyzed in L5 DRG by in situ hybridization. As anticipated, GAP-43 mRNA was induced in DRG neurons by simple intraneural injection of colchicine, and its induction by nerve transection was not blocked by proximal injection of colchicine (Fig. 2). This is the expected pattern of responses for a molecule that is induced (directly or indirectly) by interruption of retrograde transport to the nerve cell body of normal trophic influence from the distal nerve or target tissues. For IL-6 mRNA, very different responses were obtained (Figs. 2, $3)$. Injection of colchicine into the uninjured sciatic nerve did not induce IL- 6 mRNA, and injection of colchicine into the stump of a transected nerve blocked induction of IL-6 mRNA in L5 DRG 

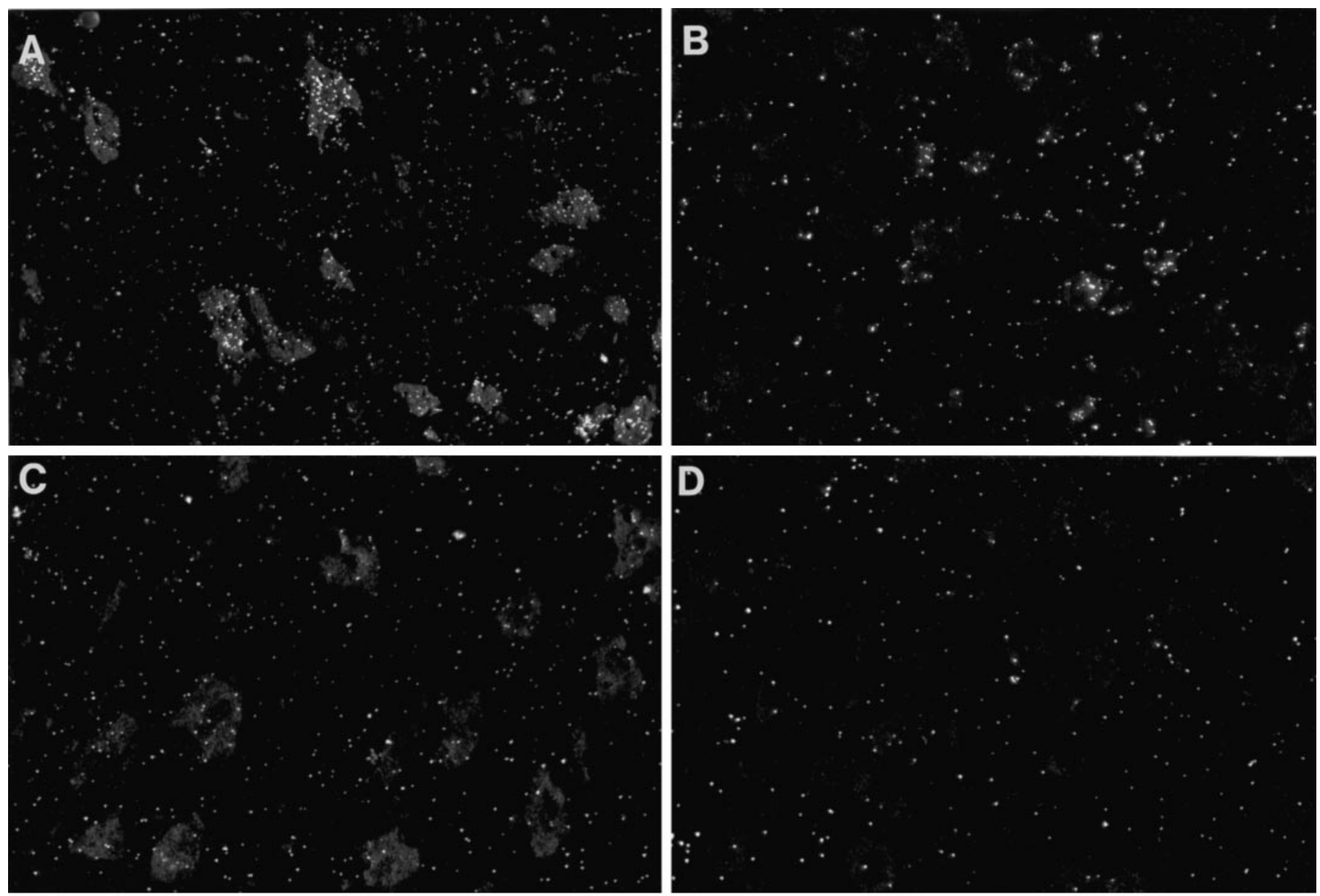

E

$\mathbf{F}$
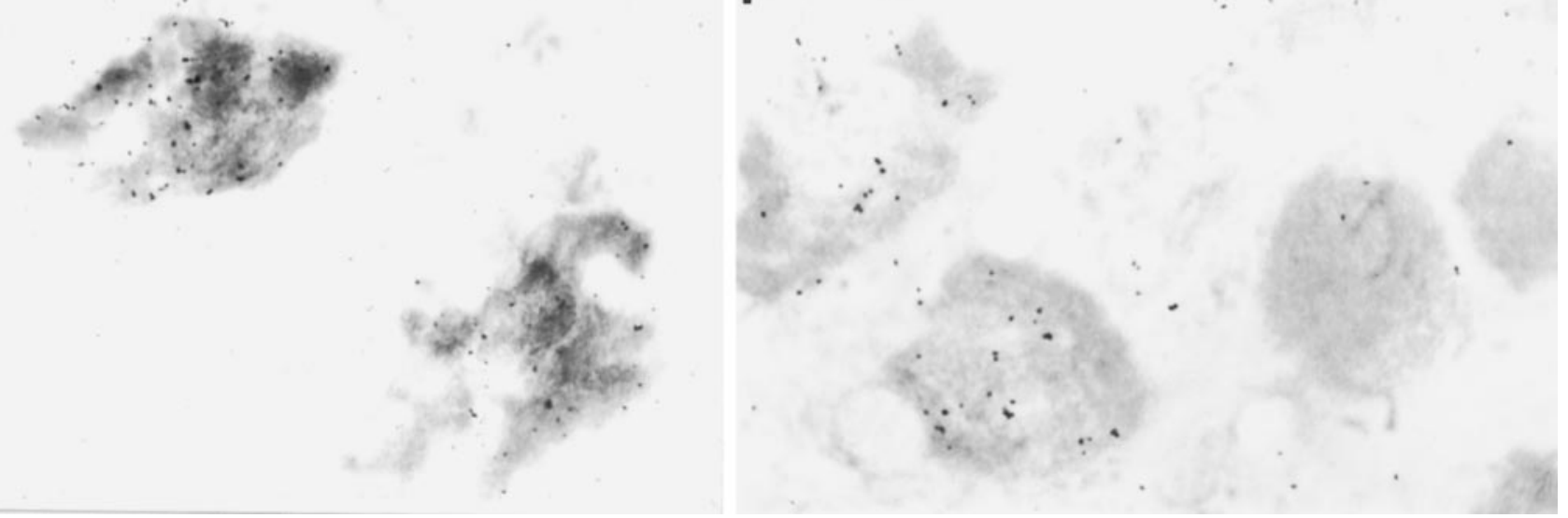

Figure 1. Dark- and light-field photomicrographs of IL-6 in situ hybridization preparations from sections through the ipsilateral $(A, E)$ or contralateral $(C)$ facial motor nucleus of a rat killed $4 \mathrm{~d}$ after unilateral facial nerve transection and of sections through the ipsilateral $(B, F)$ and contralateral $(D)$ superior cervical ganglion of rats killed $4 \mathrm{~d}$ after external and internal carotid nerve transection. Note that many neurons in the ipsilateral facial motor nucleus and some neurons in the superior cervical ganglion contain IL-6 mRNA. Magnification: $A, 230 \times ; B-D, 290 \times ; E, F, 1120 \times$.

neurons. In other control experiments, injection of colchicine into the distal segment of the transected nerve or into the contralateral nerve did not interfere with the induction of IL- 6 in axotomized DRG neurons (data not shown). Therefore, the blockage by colchicine of induction of IL-6 after nerve injury is not a nonspecific toxic effect. In previous experiments (Richardson and Verge, 1986), intraneural injection of $5 \mathrm{~mm}$ colchicine was shown to cause considerable axonal degeneration. This action of colchicine does not invalidate the conclusions of these experiments because IL- 6 is not induced, despite axonal degeneration. The results of these experiments suggest that the induction of IL-6 in injured DRG neurons is triggered by a positive signal from the injury site rather than from loss of retrograde inhibition by molecule(s) arising from the distal nerve or target tissues. 

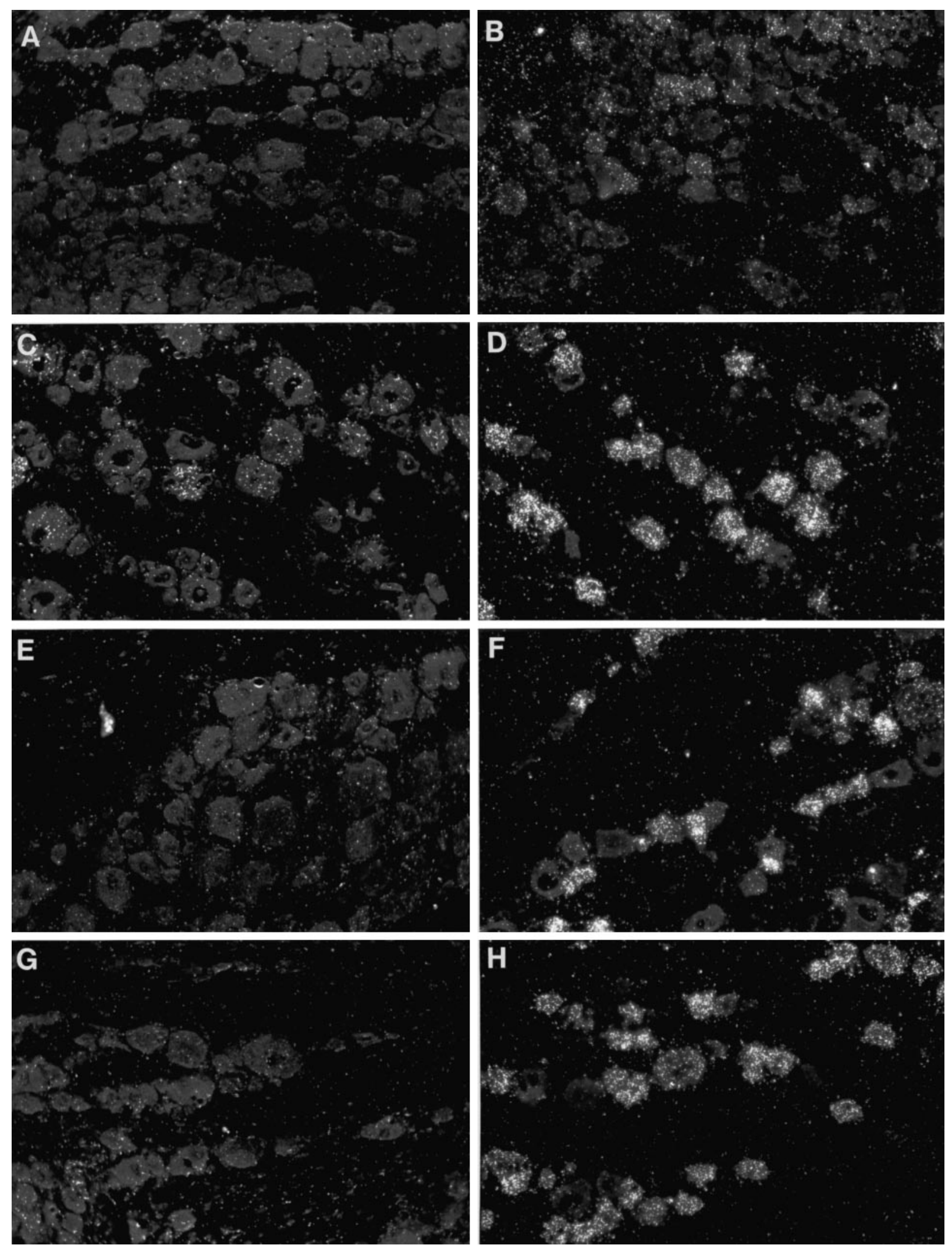

Figure 2. Dark-field photomicrographs of in situ hybridization preparations for IL-6 $(A, C, E, G)$ or GAP-43 $(B, D, F, H)$ mRNA, all of sections of L5 DRG. DRG are contralateral $(A, B)$ or ipsilateral $(C, D)$ to sciatic nerve transection, ipsilateral to intraneural injection of colchicine $(E, F)$, or ipsilateral to nerve transection plus injection of colchicine into the nerve stump $(G, H)$. Note that IL-6 mRNA is induced by nerve transection but not by intraneural injection of colchicine and that the effect of nerve transection on IL-6 mRNA is blocked by more proximal injection of colchicine. GAP-43 mRNA is also induced by nerve transection. However, in contrast to IL-6 mRNA, GAP-43 mRNA is induced by intraneural injection of colchicine, and its induction by nerve transection is not blocked by more proximal injection of colchicine. Despite longer exposure times, the signal for IL-6 mRNA is consistently weaker than that for GAP-43 mRNA, presumably because the latter is much more abundant. Magnification, $180 \times$. 

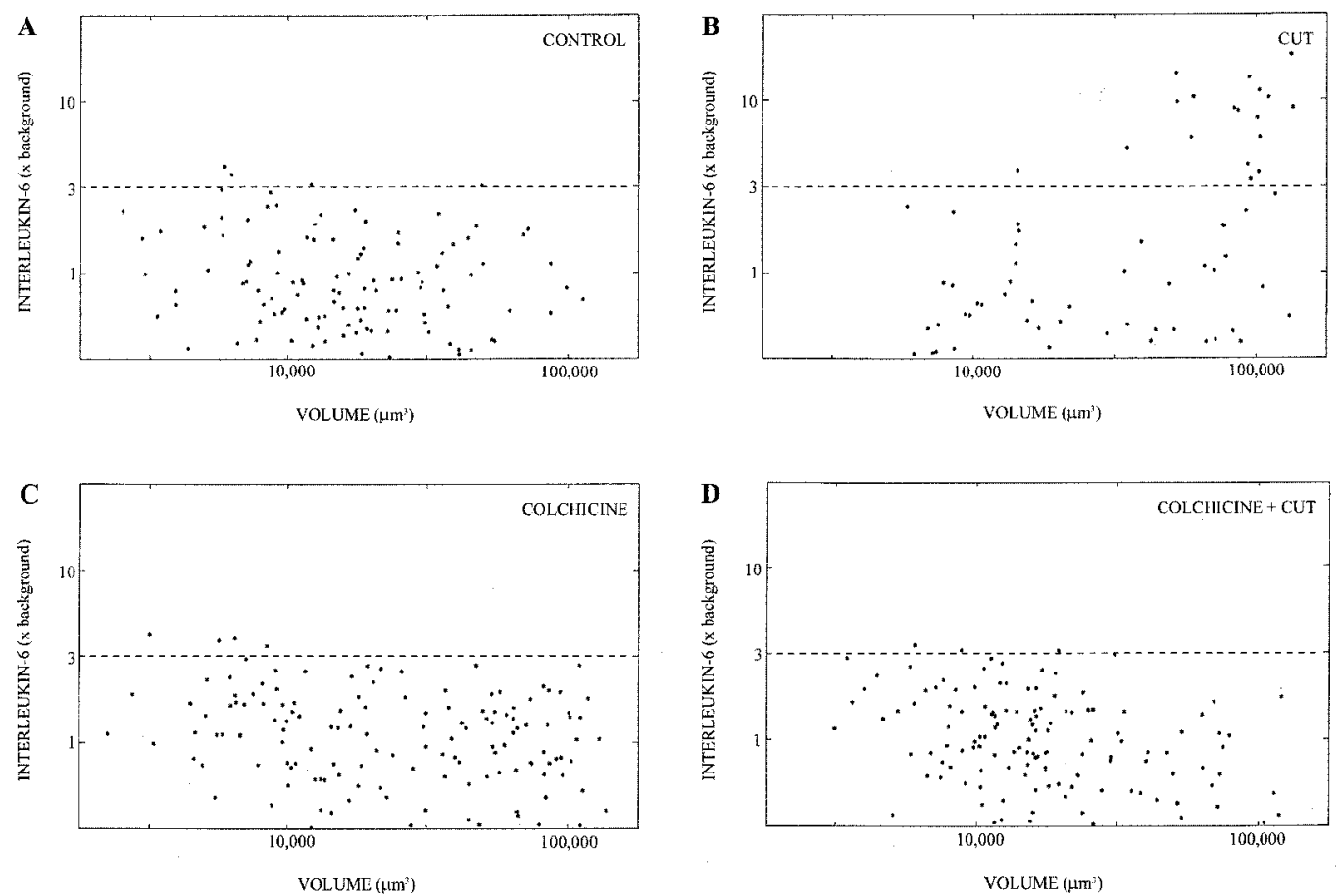

Figure 3. Quantification of IL-6 mRNA labeling by in situ hybridization. Each point represents a single DRG neuron, with labeling index as the $y$-axis and volume as the $x$-axis (log-log scale). $A$, Normal DRG. $B$, DRG removed $3 \mathrm{~d}$ after nerve transection. $C$, DRG removed $3 \mathrm{~d}$ after injection of colchicine. $D$, DRG removed $3 \mathrm{~d}$ after nerve transection plus injection of colchicine into the nerve stump. Note that many neurons with clear presence of IL-6 mRNA (more than threefold background) are found after simple nerve transection, but few or none are found in either of the experiments involving colchicine injection.

\section{Degranulation of mast cells influences IL-6 mRNA in neurons}

Injection of the mast cell degranulating agent $48 / 80$, but not saline, into the uninjured sciatic nerve induced IL-6 mRNA in medium and large neurons in the ipsilateral DRG (Figs. 4, 5). IL-6 mRNA was seen in L5 DRG removed 24 or 48, but not 6 , hr after injection of 48/80. Approximately one-fifth of neurons were seen to contain IL-6 mRNA after $48 / 80$ injection. Given that 48/80 disrupts the blood-nerve barrier (Harvey et al., 1994), we investigated whether intraneural injection of serum or surgical disruption of the blood-nerve barrier (Gentili et al., 1981) was a sufficient stimulus for IL-6 induction in neurons. Neither neurolysis nor injection of up to $5 \mu$ l of serum into the nerve induced IL-6 in DRG neurons (data not shown). These observations suggest that degranulation of endoneurial mast cells induces IL-6 mRNA in neurons by a mechanism more complicated than simple increase in vascular permeability.

Not only does degranulation of endoneurial mast cells induce IL-6 mRNA in DRG neurons, but agents that stabilize mast cells attenuate the induction of IL-6 mRNA. Injected for $5 \mathrm{~d}$ before and after nerve transection, cromolyn sodium (Fig. 4) or ketotifen (data not shown) substantially reduced the induction of IL-6 mRNA (Figs. 4, 5).

\section{Effects of cytokines on IL-6 induction}

TNF- $\alpha$ is present in the granules of resident mast cells, (Gordon and Galli, 1990), mediates the initiation of some inflammatory reactions by mast cells (Echtenacher et al., 1996; Malaviya et al., 1996), and stimulates IL-6 synthesis in many cell types (Brach et al., 1990), including cortical neurons in vitro (Ringheim et al.,
1997). Therefore, TNF- $\alpha$ was deemed to be one candidate signaling molecule from injured nerves to stimulate IL-6 synthesis in neurons. However, a single intraneural injection of TNF- $\alpha$ (100 ng) did not induce enough IL-6 mRNA in DRG neurons to be detected by in situ hybridization. In a similar manner, intraneural injection of IL-1 $\beta$ (100 ng) failed to stimulate IL-6 mRNA in DRG neurons. Although not supportive of the hypothesis that endogenous IL-1 $\beta$ and/or TNF- $\alpha$ are responsible for IL-6 mRNA induction after nerve injury, these negative results with a single technique do not exclude the possibility.

\section{Increased death of axotomized DRG neurons in IL-6 - I- mice}

Survival of neurons in L5 DRG after sciatic nerve transection was compared in IL-6 - / - and wild-type mice. IL-6 - / - mice breed well and appear normal but react abnormally to traumatic or infectious challenge (Fattori et al., 1994; Kopf et al., 1994; Ramsay et al., 1994; Chai et al., 1996; Cressman et al., 1996).

Two weeks after transection of the sciatic nerve at its origin in nine wild-type mice, the mean ratio of neuron counts in ipsilateral versus contralateral L5 DRG decreased by $30 \%$ (Table 1). In previous studies in rats, death of L5 DRG was estimated by cell counting as 14 or $23 \%$ at 10 or $30 \mathrm{~d}$ after sciatic nerve transection at midthigh (Arvidsson et al., 1986; Himes and Tessler, 1989) and, by stereology, as $22 \%$ at $15 \mathrm{~d}$ after spinal nerve transection (Vestergaard et al., 1997). The level of transection in rats in the latter study is similar to that in mice in the present study. These data indicate that, in C57BL6/129 mice, death of axotomized DRG neurons is comparable to that in rats.

The mean decrease in ratio of counts in ipsilateral versus contralateral L5 DRG after sciatic nerve transection in nine IL-6 

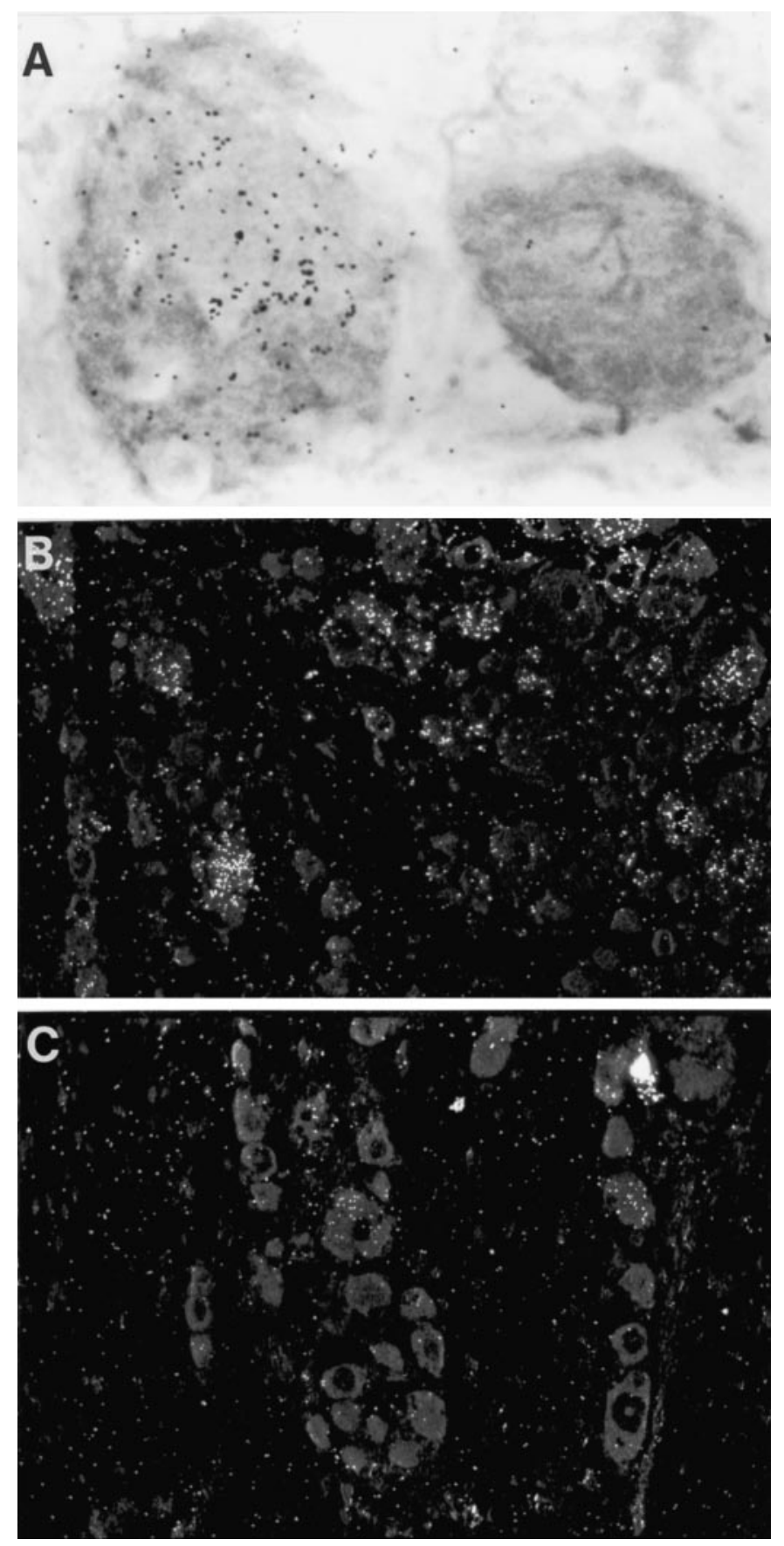

Figure 4. A, Light-field photomicrograph of IL-6 in situ hybridization preparation of L5 DRG ipsilateral to a sciatic nerve that had been injected with 48/80, a mast cell degranulating agent. One heavily labeled neuron is seen. $B$, Dark-field photomicrograph of IL-6 in situ hybridization preparation of DRG ipsilateral to transected sciatic nerve. $C$, Dark-field photomicrograph of IL-6 in situ hybridization of DRG ipsilateral to sciatic nerve transection in a rat that had also been injected intraperitoneally with a mast cell stabilizing agent, cromolyn sodium. Note that the labeling evident after nerve transection is reduced by injection of cromolyn sodium. Magnification: $A, 1120 \times ; B, C, 180 \times$.

-/ - mice was $43 \%$ (Table 1), translating to $45 \%$ more neuronal loss than in wild-type mice. We interpret the excessive decrease in neuronal numbers in L5 DRG after sciatic nerve transection in IL- $6-/-$ mice to indicate that endogenous IL- 6 induced by nerve injury contributes to the survival of injured neurons.

\section{DISCUSSION}

\section{IL-6 is induced in neurons by a positive injury signal}

The effects of intraneural injection of colchicine indicate that IL-6 induction is triggered by a positive rather than negative signal from injured nerves. Three other examples establish a precedent for this mechanism. The induction of p75 mRNA in motoneurons also appears to depend on a positive retrograde axonal signal (Moix et al., 1991; Greeson et al., 1992), although for these neurons, it is not possible to exclude an influence from degenerating terminals of the central projections of sensory neurons. The induction of galanin in DRG neurons depends in part on release of leukemia inhibitory factor (LIF) from the nerve stump (Corness et al., 1996; Sun and Zigmond, 1996) but also on release from a chronic inhibition by NGF (Verge et al., 1995; Corness et al., 1998). Perhaps the best documentation of a positive inductive signal from injured axons is for long-term hyperexcitability in Aplysia neurons (Gunstream et al., 1995).

The positive nature of the initial signal and the brief duration of IL-6 induction are unusual among the consequences of nerve injury on nerve cell bodies. Perhaps other growth factors with relatively brief induction in neurons after nerve injury, such as BDNF (Kobayashi et al., 1996; Verge et al., 1996; Averill et al., 1997; Tonra et al., 1998) and basic FGF (Ji et al., 1995), also are induced by a positive signal from the nerve and are involved in neuronal survival after axotomy.

The present studies have emphasized cellular rather than molecular signals that induce IL-6 mRNA in DRG neurons. In a variety of cell types, IL-6 synthesis is stimulated strongly by several extracellular molecules, including lipopolysaccharide (Zhang et al., 1994), IL-1 (Zhang et al., 1990), TNF- $\alpha$ (Brach et al., 1990; Ringheim et al., 1997), LIF (Villiger et al., 1993), cardiotrophin-1 (Robledo et al., 1997), oncostatin-1 (Brown et al., 1991), interferon- $\gamma$ (Faggioli et al., 1997), granulocytemacrophage colony-stimulating factor (Cicco et al., 1990), stem cell factor, (Gagari et al., 1997), histamine (Mor et al., 1995; Takamatsu and Nakao, 1998), leukotriene B4 (Brach et al., 1992) et al., 1992), prostaglandins (Leal-Berumen et al., 1995; Fiebich et al., 1997), and reactive oxidative species (Shibanuma et al., 1994). With respect to intracellular signaling, IL-6 gene expression is dominated by NF- $\kappa$ B (Zhang et al., 1990; Lord et al., 1991; Sha et al., 1995) but is influenced by other transcription factors, such as NF-IL-6 (Matsusaka et al., 1993; Zhang et al., 1994), Sp1 (Kang et al., 1996), and AP-1 (Dendorfer et al., 1994), plus the transcription repressor recombination signal sequence binding protein (Kannabiran et al., 1997). NF- $\kappa \mathrm{B}$ is constitutively expressed in neurons (Kaltschmidt et al., 1994), where it is perturbed by nerve injury (Doyle and Hunt, 1997; Ma and Bisby, 1998). Candidate molecules for the initiation of the signaling that induces IL- 6 in neurons must be present in injured nerves, are likely to be among those that are known to stimulate IL-6 synthesis in non-neuronal cells, probably activate the NF- $\kappa$ B signaling pathway, and should have receptors on some but not all axons.

\section{Possible implication of mast cells in induction of IL- 6 mRNA in neurons}

Intraneural injection of $48 / 80$ was sufficient stimulus to induce IL-6 mRNA in neurons. It seems probable that this effect of 48/80 was attributable to mast cell degranulation rather than nonspecific tissue damage or inflammation. Doses of 48/80 slightly higher than used here do not induce gross axonal damage or wallerian degeneration, and axonal interruption alone is not sufficient to induce IL-6 synthesis in neurons. One possible mechanism of 

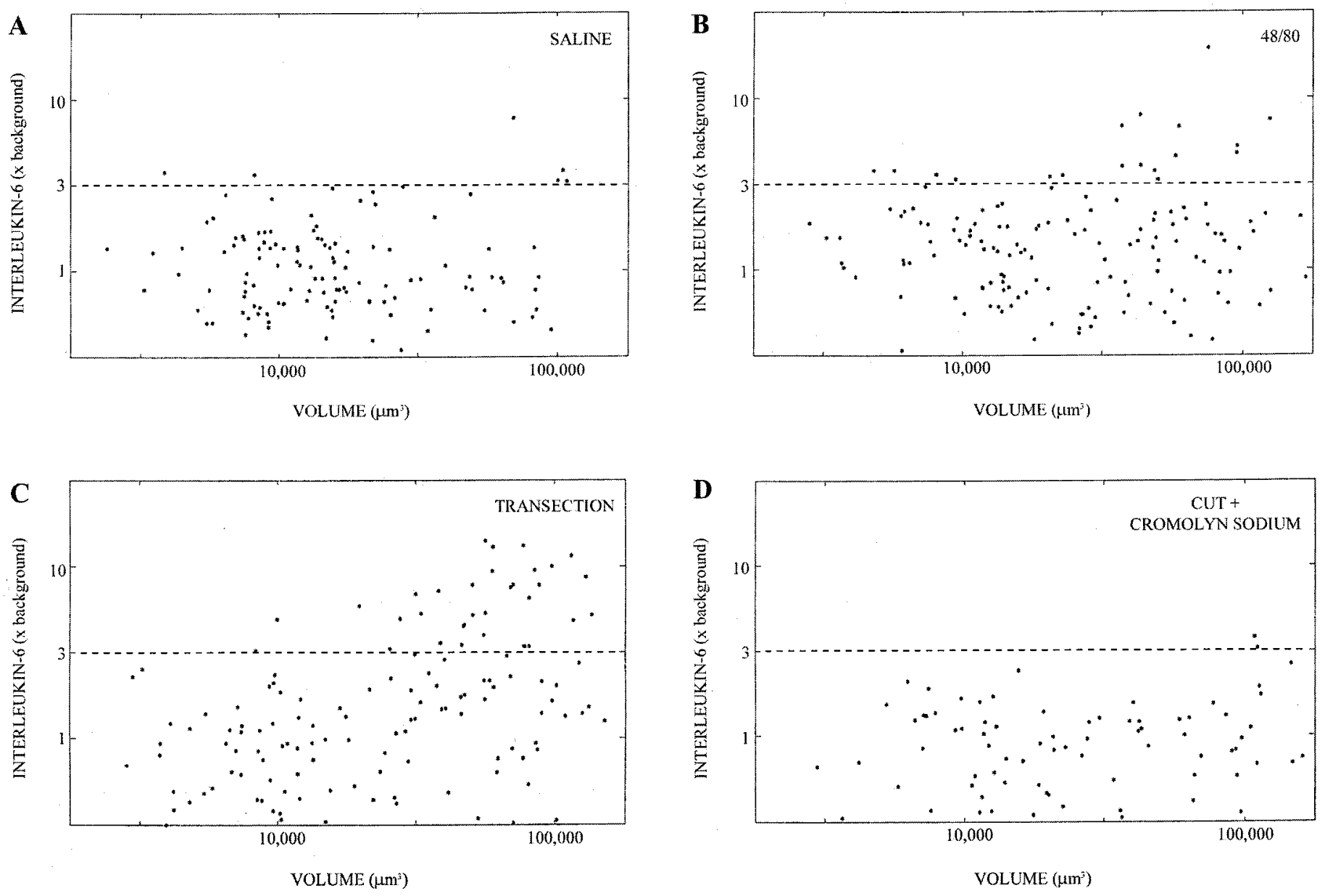

Figure 5. Quantification of IL-6 mRNA labeling to show the effects of 48/80 and cromolyn sodium. Again, each point represents a single DRG neuron, with labeling index as the $y$-axis and volume as the $y$-axis $(\log -\log$ scale). $A$, DRG associated with nerve injected with $48 / 80$. $B$, DRG associated with nerve injected with saline. $C$, DRG associated with nerve transected $5 \mathrm{~d}$ previously. $D$, DRG associated with nerve transected $5 \mathrm{~d}$ previously with intraperitoneal injection of cromolyn for $5 \mathrm{~d}$ before and after nerve transection. Note that $48 / 80$ mimics and cromolyn sodium blocks the induction of IL-6 mRNA by nerve transection.

Table 1. Neuronal counts in L5 DRG of wild-type and IL-6 -/- mice $14 \mathrm{~d}$ after sciatic nerve transection

\begin{tabular}{llll} 
& Contralateral & Ipsilateral & Ratio (I/C) \\
\hline WT & $3555 \pm 201$ & $2470 \pm 134$ & $70 \pm 2$ \\
KO & $3268 \pm 261$ & $1840 \pm 157$ & $57 \pm 4^{*}$
\end{tabular}

Neurons with distinct nucleoli were counted by a blinded observer in every fifth section from contralateral and ipsilateral DRG removed 2 weeks after sciatic nerve transection (mean \pm SEM; $n=9$ mice in each group). Note that the mean of the ratios is not the same as the ratio of the means. ${ }^{*} p<0.05$ by Student's $t$ test or Mann-Whitney rank sum test. Neuronal counts in the contralateral DRG tended to be lower in IL-6 - - mice than wild-type mice, but this trend did not reach statistical significance. WT, Wild-type mice; KO, IL-6 -/- mice.

action of 48/80 is breakdown of the blood-nerve barrier (Harvey et al., 1994). However, neither increasing of the permeability of nerve vasculature by surgical manipulation nor injection of serum was sufficient to induce IL-6 mRNA in DRG neurons. We conclude that one or more of the molecules released from degranulated mast cells triggers a retrograde axonal signal that induces IL-6 mRNA.

Two agents that interfere with mast cell degranulation also mitigate the induction of IL- 6 in neurons after nerve injury. Although the actions of these pharmacological agents may not be restricted to mast cells, the observations again are consistent with the hypothesis that mast cells in the stump of a transected nerve are a source of retrograde signals that induce IL-6 synthesis in DRG neurons.

Mast cells are known best for IgE-dependent responses to parasites and detrimental allergic reactions. However, mast cells have been shown recently to counteract bacterial infection and stimulate neutrophil extravasation, both actions mediated through the release of TNF- $\alpha$ (Echtenacher et al., 1996; Malaviya et al., 1996). Results of the present experiments raise the possibility that mast cells have a beneficial action in the PNS: stimulation of synthesis of IL-6 to support axotomized neurons.

\section{Endogenous IL-6 contributes to neuronal survival after nerve injury}

Endogenous IL-6 mitigates the death of sensory neurons after axotomy. This statement is justified by evidence that the decrease in neuronal numbers in L5 DRG after nerve transection is $45 \%$ greater in IL-6 -/- mice than in control mice.

Whereas the absence of endogenous IL- 6 in mutant mice results in the death of sensory neurons after axotomy, infusion of exogenous IL-6 was not found to counteract death of facial motor neurons after injury in newborn rats (Li et al., 1994). One possible explanation for this paradox is that IL-6 is induced to biologically 
effective concentrations in the immediate vicinity of axotomized neurons (Murphy et al., 1995) so that exogenous IL-6 is superfluous in this circumstance.

The lack of IL-6 in mutant mice is not compensated by CNTF or LIF, which are active on DRG neurons and use gp130 as their signaling receptor. In contrast, null mutation of the LIF or CNTF gene alone does not impair neuronal survival after axotomy, although mutation of both genes does lead to increased neuronal death (Sendtner et al., 1996). Also, the absence of LIF in mutant mice has noncompensable consequences on neuropeptide synthesis in axotomized sympathetic and sensory neurons (Rao et al., 1993; Corness et al., 1996; Sun and Zigmond, 1996). The lack of compensation in the present experiments may reflect different sites of synthesis for the three cytokines; only IL- 6 is synthesized in DRG neurons after nerve injury (Sendtner et al., 1992; Seniuk et al., 1992; Banner and Patterson, 1994; Curtis et al., 1994; Murphy et al., 1995).

Although IL-6 is neurotoxic under some circumstances (Campbell et al., 1993), endogenous IL-6 supports axotomized neurons just as another cytokine with toxic properties, TNF- $\alpha$, supports ischemic neurons (Bruce et al., 1997).

A major negative signal, interruption of retrograde trophic support, leads to the death of many DRG neurons after nerve injury. Results of our experiments indicate that an additional positive signal leads to induction of IL-6, which counteracts the tendency to neuronal death.

\section{REFERENCES}

Aldskogius H, Svensson M (1988) Effect on the rat hypoglossal nucleus of vinblastine and colchicine applied to the intact or transfected hypoglossal nerve. Exp Neurol 99:461-473.

Arvidsson J, Ygge J, Grant G (1986) Cell loss in lumbar dorsal root ganglia and transganglionic degeneration after sciatic nerve resection in the rat. Brain Res 373:15-21.

Averill S, Michael GJ, Shortland PJ, Priestley JV (1997) BDNF increases in large diameter dorsal root ganglion cells and their central projections following peripheral axotomy. Soc Neurosci Abstr 23:327.

Banner LR, Patterson PH (1994) Major changes in the expression of the mRNAs for cholinergic differentiation factor/leukemia inhibitory factor and its receptor following injury to adult peripheral nerves and ganglia. Proc Natl Acad Sci USA 91:7109-7113.

Beitz AJ, King GW (1979) An improved technique for the microinjection of horseradish peroxidase. Brain Res 108:175-179.

Bennett DLH, Michael GJ, Ramachandran N, Munson JB, Averill S, Yan Q, McMahon SB, Priestley JV (1998) A distinct group of small DRG cells express GDNF receptor components and GDNF is protective for these neurons after nerve injury. J Neurosci 18:3059-3072.

Berkelaar M, Clarke DB, Wang Y-C, Bray GM, Aguayo AJ (1994) Axotomy results in delayed death and apoptosis of retinal ganglion cells in adult rats. J Neurosci 14:4368-4374.

Bourde O, Kiefer R, Toyka KV, Hartung H-P (1999) Quantification of interleukin- 6 mRNA in wallerian degeneration by competitive reverse transcription polymerase chain reaction. J Neuroimmunol 69:135-140.

Brach MA, Cicco NA, Riedel D, Hirano T, Kishimoto T, Mertelsmann RH, Herrmann F (1990) Mechanisms of differential regulation of interleukin- 6 mRNA accumulation by tumor necrosis factor $\alpha$ and lymphotoxin during monocytic differentiation. FEBS Lett 263:349-354.

Brach MA, de Vos S, Arnold C, Gruss H-J, Mertelsmann R, Herrmann F (1992) Leukotriene B4 transcriptionally activates interleukin-6 expression involving NF-KB and NF-IL6. Eur J Immunol 22:2705-2711.

Brosman CF, Lyman WD, Tansey FA, Carter TH (1985) Quantitation of mast cells in experimental allergic neuritis. J Neuropathol Exp Neurol 44:196-203.

Brown TJ, Rowe JM, Liu J, Shoyab M (1991) Regulation of IL-6 expression by oncostatin M. J Immunol 147:2175-2180.

Bruce AJ, Boling W, Kindy MS, Peschon J, Kraemer PJ, Carpenter MK, Holtsberg FW, Mattson MP (1997) Altered neuronal and microglial responses to excitotoxic and ischemic brain injury in mice lacking TNF receptors. Nat Med 2:788-794.

Campbell IL, Abraham CR, Masliah E, Kemper P, Inglis JD, Oldstone MBA, Mucke L (1993) Neurologic disease induced in transgenic mice by cerebral overexpression of interleukin 6. Proc Natl Acad Sci USA 90:10061-10065.

Carmel PW, Stein BM (1969) Cell changes in sensory ganglia following proximal and distal nerve section in the monkey. J Comp Neurol 135:145-166.

Chai Z, Gatti S, Poli V, Bartfai T (1996) Interleukin (IL)-6 gene expression in the central nervous system is necessary for fever response to lipopolysaccharide or IL-1 $\beta$ : a study on IL-6-deficient mice. J Exp Med 183:311-316.

Chong MS, Reynolds ML, Irwin N, Coggeshall RE, Emson PC, Benowitz LI, Woolf CJ (1994) GAP-43 expression in primary sensory neurons following central axotomy. J Neurosci 14:4375-4384.

Cicco NA, Lindemann A, Content J, Vandenbussche P, Lübbert M, Gauss J, Mertelsmann R, Herrmann F (1990) Inducible production of interleukin- 6 by human polymorphonuclear neutrophils: role of granulocyte-macrophage colony-stimulating factor and tumor necrosis factor- $\alpha$. Blood 75:2049-2052.

Corness J, Shi TJ, XU ZQ, Brulet P, Hökfelt T (1996) Influence of leukemia inhibitory factor on galanin/GMAP and neuropeptide $\mathrm{Y}$ expression in mouse primary sensory neurons after axotomy. Exp Brain Res 112:79-88.

Corness J, Stevens B, Fields RD, Hökfelt T (1998) NGF and LIF both regulate galanin gene expression in primary DRG cultures. NeuroReport 9:1533-1536.

Cressman DE, Greenbaum LE, DeAngelis RA, Ciliberto G, Furth EE, Poli V, Taub R (1996) Liver failure and defective hepatocyte regeneration in interleukin-6-deficient mice. Science 274:1379-1383.

Cummins TR, Waxman SG (1998) Downregulation of tetrodotoxinresistant sodium currents and upregulation of a rapidly repriming tetrodotoxin-sensitive sodium current in small spinal sensory neurons after nerve injury. J Neurosci 17:3503-3514.

Curtis R, Scherer SS, Somogyi R, Adryan KM, Ip NY, Zhu Y, Lindsay RM, DiStefano PS (1994) Retrograde axonal transport of LIF is increased by peripheral nerve injury: correlation with increased LIF expression in distal nerve. Neuron 12:191-204.

Dendorfer U, Oettgen P, Libermann TA (1994) Multiple regulatory elements in the interleukin- 6 gene mediate induction by prostaglandins, cyclic AMP, and lipopolysaccharide. Mol Cell Biol 14:4443-4451.

Dines KC, Powell HC (1997) Mast cell interactions with the nervous system: relationship to mechanisms of disease. J Neuropathol Exp Neurol 56:627-640.

Doyle CA, Hunt SP (1997) Reduced nuclear factor $\kappa$ B expression in rat primary sensory neurons after peripheral nerve injury. NeuroReport 8:2937-2942.

Echtenacher B, Mannel DN, Hultner L (1996) Critical protective role of mast cells in a model of acute septic peritonitis. Nature 381:75-77.

Faggioli L, Merola M, Hiscott J, Furia A, Monese R, Tovey M, Palmieri M (1997) Molecular mechanisms regulating induction of interleukin-6 gene transcription by interferon- $\gamma$. Eur J Immunol 27:3022-3030.

Fattori E, Cappelletti M, Costa P, Sellitto C, Cantoni L, Carelli M, Faggioni R, Fantuzzi G, Ghezzi P, Poli V (1994) Defective inflammatory response in interleukin-6-deficient mice. J Exp Med 180:1243-1250.

Fiebich BL, Hull M, Lieb K, Gyufko K, Berger M, Bauer J (1997) Prostaglandin E2 induces interleukin-6 synthesis in human astrocytoma cells. J Neurochem 68:704-709.

Fitzgerald M, Wall PD, Goedert M, Emson PC (1985) Nerve growth factor counteracts the neurophysiological and neurochemical effects of chronic sciatic nerve section. Brain Res 332:131-141.

Gagari E, Tsai M, Lantz CS, Fox LG, Galli SJ (1997) Differential release of mast cell interleukin-6 via c-kit. Blood 89:2654-2663.

Galli SJ (1993) New concepts about the mast cell. N Engl J Med 328:257-265.

Gentili F, Hudson AR, Kline DG, Hunter D (1981) Morphological and physiological alterations following internal neurolysis of normal rat sciatic nerve. In: Posttraumatic peripheral nerve regeneration (Gorio A, ed), pp 183-196. New York: Raven.

Gordon JR, Galli SJ (1990) Mast cells as a source of both preformed and immunologically inducible TNF- $\alpha$ /cachectin. Nature 346:274-276.

Gordon T, Gillespie J, Orozco R, Davis L (1991) Axotomy-induced 
changes in rabbit hindlimb nerves and the effects of chronic electrical stimulation. J Neurosci 11:2157-2169.

Greeson DM, Moix L, Meier M, Armstrong DM, Wiley RG (1992) A continuing signal maintains NGF receptor expression in hypoglossal motor neurons after crush injury. Brain Res 594:351-355.

Gunstream J, Castro GA, Walters ET (1995) Retrograde transport of plasticity signals in Aplysia sensory neurons following axonal injury. J Neurosci 15:439-448.

Hare WK, Hinsey JC (1940) Reactions of dorsal root ganglion cells to section of peripheral and central processes. J Comp Neurol 73:489-502.

Harvey GK, Toyka KV, Hartung H-P (1994) Effects of mast cell degranulation on blood-nerve barrier permeability and nerve conduction in vivo. J Neurol Sci 125:102-109.

Himes BT, Tessler A (1989) Death of some dorsal root ganglion neurons and plasticity of others following sciatic nerve section in adult and neonatal rats. J Comp Neurol 284:215-230.

Hökfelt T, Zhang X, Wiesenfeld-Hallin Z (1994) Messenger plasticity in primary sensory neurons following axotomy and its functional implications. Trends Neurosci 17:22-30.

Jenkins R, McMahon SB, Bond AB, Hunt SP (1993) Expression of c-Jun as a response to dorsal root and peripheral nerve section in damaged and adjacent intact primary sensory neurons in the rat. Eur J Neurosci 5:751-759.

Ji RR, Zhang Q, Zhang X, Piehl F, Reilly T, Petterson RF, Hökfelt T (1995) Prominent expression of bFGF in dorsal root ganglia after injury. Eur J Neurosci 7:2458-2468.

Kaltschmidt C, Kaltschmidt B, Neumann H, Wekerle H, Baeuerle PA (1994) Constitutive NF- $\kappa$ B activity in neurons. Mol Cell Biol 14:3981-3992.

Kang S-H, Brown DA, Kitajima I, XU X, Heidenreich O, Gryaznov S, Nerenberg M (1996) Binding and functional effects of transcriptional factor $\mathrm{Sp} 1$ on the murine interleukin-6 promoter. J Biol Chem 271:7330-7335.

Kannabiran C, Zeng X, Vales L (1997) The mammalian transcription repressor $\mathrm{RBP}(\mathrm{CBF} 1)$ regulates interleukin-6 gene expression. Mol Cell Biol 17:1-9.

Kiefer R, Lindholm D, Kreutzberg GW (1993) Interleukin-6 and transforming growth factor- $\beta 1$ mRNAs are induced in rat facial nucleus following motoneuron axotomy. Eur J Neurosci 5:775-781.

Klein MA, Moller JC, Jones LL, Bluethmann H, Kreutzberg G, Raivich G (1997) Impaired neuroglial activation in interleukin-6 deficient mice. Glia 19:227-233.

Kobayashi NR, Bedard AM, Hincke MT, Tetzlaff W (1996) Increased expression of BDNF and trkB mRNA in rat facial motoneurons after axotomy. Eur J Neurosci 8:1018-1029.

Kopf M, Baumann H, Freer G, Freudenberg M, Lamers M, Kishimoto T, Zinkernagel R, Bluethmann H, Köhler G (1994) Impaired immune and acute-phase responses in interleukin-6-deficient mice. Nature 368:339-342.

Kubes P, Granger DN (1996) Leukocyte-endothelial cell interactions evoked by mast cells. Cardiovasc Res 32:699-708.

Landmesser L, Pilar G (1974) Synaptic transmission and cell death during normal ganglionic development. J Physiol (Lond) 241:737-749.

Leah JD, Herdegen T, Bravo R (1991) Selective expression of Jun proteins following axotomy and axonal transport block in peripheral nerves in the rat: evidence for a role in the regeneration process. Brain Res 566:198-207.

Leal-Berumen I, O'Byrne P, Gupta A, Richards CD, Marshall JS (1995) Prostanoid enhancement of interleukin-6 production by rat peritoneal mast cells. J Immunol 154:4759-4767.

Lewin GR, Mendell LM (1994) Peripheral and central mechanisms of NGF-induced hyperalgesia. Eur J Neurosci 6:1903-1912.

Li L, Oppenheim RW, Lei M, Houenou LJ (1994) Neurotrophic agents prevent motoneuron death following sciatic nerve section in the newborn mouse. J Neurobiol 25:759-766.

Lieberman AR (1971) The axon reaction: a review of the principal features of perikaryal responses to axonal injury. Int Rev Neurobiol 14:49-124.

Lieberman AR (1974) Some factors affecting retrograde neuronal responses to axonal lesions. In: Essays on the nervous system (Bellairs R, Gray EG, eds), pp 71-105. Oxford: Clarendon.

Lord KA, Abdollahi A, Thomas SM, DeMarco M, Brugge JS, HoffmanLiebermann B, Liebermann DA (1991) Leukemia inhibitory factor and interleukin-6 trigger the same immediate early response, including tyrosine phosphorylation, upon induction of myeloid leukemia differentiation. Mol Cell Biol 11:4371-4379.

Ma W, Bisby MA (1998) Increased activation of nuclear factor $\kappa \mathrm{B}$ in rat lumbar dorsal root ganglion neurons following partial sciatic nerve injuries. Brain Res 797:243-254.

Malaviya R, Ikeda T, Ross E, Abraham SN (1996) Mast cell modulation of neutrophil influx and bacterial clearance at sites of infection through TNF- $\alpha$. Nature 381:77-80.

Marz P, Gadient RA, Otten U (1996) Expression of interleukin-6 receptor and gp130 in PC-12 cells and sympathetic neurons: modulation by tumor necrosis factor. Brain Res 706:71-79.

Matsusaka T, Fujikawa K, Nishio Y, Mukaida N, Matsushima K, Kishimoto T, Akira S (1993) Transcription factors NF-IL6 and NF- $\kappa$ B synergistically activate transcription of the inflammatory cytokines, interleukin 6 and interleukin 8. Proc Natl Acad Sci USA 90:10193-10197.

McQuarrie IG, Grafstein B (1973) Axon outgrowth enhanced by a previous nerve injury. Arch Neurol 29:53-55.

Moix LJ, Greeson DM, Armstrong DM, Wiley RG (1991) Separate signals mediate hypoglossal motor neuron response to axonal injury. Brain Res 564:176-180.

Mor S, Nagler A, Barak V, Handzel ZT, Geller-Bernstein C, Fabian I (1995) Histamine enhances granulocyte-macrophage colonystimulating factor and interleukin-6 production by human peripheral blood mononuclear cells. J Leukoc Biol 58:445-450.

Murphy PG, Grondin J, Altares M, Richardson PM (1995) Induction of interleukin-6 in axotomized sensory neurons. J Neurosci 15:5130-5138.

Olsson Y (1967) Degranulation of mast cells in peripheral nerve injuries. Acta Neurol Scand 43:365-374.

Pettmann B, Henderson CE (1998) Neuronal cell death. Neuron 20:633-647.

Ramsay AJ, Husband AJ, Ramshaw IA, Bao S, Matthaei KI, Koehler G, Kopf M (1994) The role of interleukin-6 in mucosal IgA antibody responses in vivo. Science 264:561-563.

Rao MS, Sun Y, Escary JL, Perreau J, Tresser S, Patterson PH, Zigmond RE, Brulet P, Landis SC (1993) Leukemia inhibitory factor mediates an injury response but not a target-directed developmental transmitter switch in sympathetic neurons. Neuron 11:1175-1185.

Richardson PM, Issa VMK (1984) Peripheral injury enhances central regeneration of primary sensory neurons. Nature 309:791-793.

Richardson PM, Verge VMK (1986) The induction of a regenerative propensity in sensory neurons following peripheral axonal injury. J Neurocytol 15:585-594.

Richardson PM, Verge VMK, Riopelle RJ (1989) Quantitative radioautography for NGF receptors. In: Nerve growth factors (Rush RA, ed), pp 315-326. Chichester, UK: Wiley.

Ringheim GE, Burgher KL, Heroux JA (1997) Interleukin-6 mRNA expression by cortical neurons in culture: evidence for neuronal sources of interleukin-6 production in the brain. J Neuroimmunol 63:113-123.

Robledo O, Chevalier S, Froger J, Bartelais-Pouplard A, Pennica D, Gascan H (1997) Regulation of interleukin-6 expression by cardiotrophin 1. Cytokine 9:666-671.

Sendtner M, Stockli KA, Thoenen H (1992) Synthesis and localization of ciliary neurotrophic factor in the sciatic nerve of the adult rat after lesion and during development. J Cell Biol 118:139-148.

Sendtner M, Götz R, Holtmann B, Escary J-L, Masu Y, Carroll P, Wolf E, Brem G, Brûlet P, Thoenen H (1996) Cryptic physiological trophic support of motoneurons by LIF revealed by double gene targeting of CNTF and LIF. Curr Biol 6:686-694.

Seniuk N, Altares M, Dunn R, Richardson PM (1992) Decreased synthesis of ciliary neurotrophic factor in degenerating peripheral nerves. Brain Res 572:300-302.

Sha WC, Liou H-C, Tuomanen EI, Baltimore D (1995) Targeted disruption of the $\mathrm{p} 50$ subunit of NF- $\kappa \mathrm{B}$ leads to multifocal defects in immune responses. Cell 80:321-330.

Shibanuma M, Kuroka T, Nose K (1994) Inhibition by $N$-acetyl-Lcysteine of interleukin- 6 mRNA induction and activation of NF- $\kappa B$ by tumor necrosis factor $\alpha$ in a mouse fibroblast cell line. FEBS Lett 353:62-66.

Skene JHP (1989) Axonal growth associated proteins. Annu Rev Neurosci 12:127-156.

Sun Y, Zigmond R (1996) Leukaemia inhibitory factor induced in the sciatic nerve after axotomy is involved in the induction of galanin in sensory neurons. Eur J Neurosci 8:2213-2220.

Takamatsu S, Nakao K (1998) Regulation of interleukin-6 and macro- 
phage colony stimulating factor mRNA levels by histamine in stromal cell line (MC3T3-G2/PA6). Inflamm Res 47:221-226.

Tonra JR, Curtis R, Wong V, Cliffer KD, Park JS, Timmes A, Nguyen T, Lindsay RM, Acheson A, DiStefano P (1998) Axotomy upregulates the anterograde transport and expression of brain-derived neurotrophic factor by sensory neurons. J Neurosci 18:4374-4383.

Verge VMK, Tetzlaff W, Richardson PM, Bisby MA (1990) Correlation between GAP43 and nerve growth factor receptors in rat sensory neurons. J Neurosci 10:926-934.

Verge VMK, Richardson PM, Wiesenfeld-Hallin Z, Hökfelt T (1995) Differential influence of nerve growth factor on neuropeptide expression in vivo. J Neurosci 15:2081-2096.

Verge VMK, Gratto KA, Karchewski LA, Richardson PM (1996) Neurotrophins and nerve injury in the adult. Philos Trans R Soc Lond B Biol Sci 351:423-430.

Vestergaard S, Tandrup T, Jakobsen J (1997) Effect of permanent axotomy on number and volume of dorsal root ganglion cell bodies. J Comp Neurol 388:307-312.

Villiger PM, Geng Y, Lotz M (1993) Induction of cytokine expression by leukemia inhibitory factor. J Clin Invest 91:1575-1581.

Wershil BK, Murakami T, Galli SJ (1988) Mast cell-dependent amplification of an immunologically nonspecific inflammatory response. J Immunol 140:2356-2360.
Woolf CJ, Reynolds ML, Molander C, O'Brien C, Lindsay RM, Benowitz LI (1990) The growth-associated protein GAP-43 appears in dorsal root ganglion cells and in the dorsal horn of the rat spinal cord following peripheral nerve injury. Neuroscience 34:465-478.

Woolf CJ, Ma Q-P, Allchorne A, Poole S (1996) Peripheral cell types contributing to the hyperalgesic action of nerve growth factor in inflammation. J Neurosci 16:2716-2723.

Zhang JM, Donnelly DF, Song XJ, Lamotte RH (1997) Axotomy increases the excitability of dorsal root ganglion cells with unmyelinated axons. J Neurophysiol 78:2790-2794.

Zhang Y, Lin J-X, Vilcek J (1990) Interleukin-6 induction by tumor necrosis factor and interleukin-1 in human fibroblasts involves activation of a nuclear factor binding to a $\kappa \mathrm{B}-$ like sequence. Mol Cell Biol 10:3818-3823.

Zhang Y, Broser M, Rom WN (1994) Activation of the interleukin 6 gene by Mycobacterium tuberculosis or lipopolysaccharide is mediated by nuclear factors NF-IL6 and NF- $\kappa$ B. Proc Natl Acad Sci USA 91:2225-2229.

Zhong J, Heumann R (1995) Lesion-induced interleukin-6 mRNA expression in rat sciatic nerve. Ann NY Acad Sci 762:488-490.

Zochodne DW, Nguyen C, Sharkey K (1994) Accumulation and degranulation of mast cells in experimental neuromas. Neurosci Lett 182:3-6. 